\title{
Editorial
}

\section{Special Issue: Formation and Function of Fungal Ascospores}

\author{
Aaron M. Neiman (D)
}

check for

updates

Citation: Neiman, A.M. Special Issue: Formation and Function of Fungal Ascospores. J. Fungi 2021, 7, 618. https://doi.org/10.3390/ jof7080618

Received: 21 July 2021

Accepted: 28 July 2021

Published: 29 July 2021

Publisher's Note: MDPI stays neutral with regard to jurisdictional claims in published maps and institutional affiliations.

Copyright: (C) 2021 by the author. Licensee MDPI, Basel, Switzerland. This article is an open access article distributed under the terms and conditions of the Creative Commons Attribution (CC BY) license (https:/ / creativecommons.org/licenses/by/ $4.0 /)$.
Department of Biochemistry and Cell Biology, Stony Brook University, Stony Brook, NY 11794-5215, USA; aaron.neiman@stonybrook.edu

I wish to thank all of the authors who contributed papers to this Special Issue on the Formation and Function of Ascospores. While the process of ascospore formation is most extensively studied in Saccharomyces cerevisiae, it is highly conserved throughout the ascomycetes. The work described here touches on many aspects of the process including control of entry, formation and dissolution of the limiting membrane, and construction and function of the spore wall in a variety of ascomycetes.

Ascospore formation is usually linked to meiosis. However, it is not clear if this is the case in Ashbya gossypii. Wendland provides a timely review of spore formation in A. gossypii, highlighting similarities and the differences with $S$. cerevisiae [1]. The environmental conditions that induce this developmental program vary between fungi. Wasserstrom and Wendland and Jun et al. report on factors controlling entry into the sporulation program in A. gossypii and Aspergillus flavus, respectively [2,3].

Earlier work has shown that Schizosaccharomyces pombe cells undergo 'virtual nuclear envelope breakdown' (vNEBD) in Meiosis II, in which nuclear proteins equilibrate into the cytoplasm [4]. Yang et al. show that release of the proteasome subunit Rpn11 via vNEBD is required for proper closure of the forespore membrane (the S. pombe name for the prospore membrane) and spore formation [5]. In S. cerevisiae, Durant et al. demonstrate that the transient localization of the MAP kinase Smk1 to the lip of the prospore membrane is required for proper membrane closure and spore morphogenesis [6]. Capture of the nucleus by a prospore (or forespore) membrane results in cells that are surrounded by two membranes; the spore plasma membrane closest to the nucleus, and an outer membrane which disappears during the process of spore wall assembly [7]. Zhang et al. identify the first mutants defective in outer membrane lysis and characterize the consequences of this defect in S. pombe [8].

The spore wall is the defining feature of the ascospore, and four studies added to our understanding of the organization of this remarkable extracellular matrix. Tahara et al. have used a quick-freeze deep etch electron microscopy technique to reveal the architecture of the surface layers of the S. pombe spore wall [9]. The spore wall of S. cerevisiae contains an outer layer consisting of a polymer of the di-amino acid dityrosine. Basiony et al. characterize the product of the Dit1 enzyme, responsible for the first step in dityrosine synthesis [10]. In addition to dityrosine, the outer spore wall of $S$. cerevisiae is composed of chitosan and a third, uncharacterized component [11]. Chrissian et al. demonstrate that this third component is a tryglyceride, and that a similar set of constituents-chitosan, neutral lipid, and a polyphenol polymer-are a conserved feature of the melanized cell wall of the basidiomycete Cryptococcus neoformans [12]. The ascospores of Talaromyces macrosporus are highly stress resistant and will not germinate unless first exposed to extremes of heat or pressure. Dijksterhuis et al. identify a small protein that is released from the spore wall under germination conditions and characterize the phenotype of spores lacking this key spore wall component [13].

The papers of this Special Issue highlight the fascinating cell biology of this highly conserved developmental process. My thanks again to all of the contributors.

Funding: Research in the Neiman Laboratory is supported by NIH Grant GM072540. 
Conflicts of Interest: The author declares no conflict of interest.

\section{References}

1. Wendland, J. Sporulation in Ashbya gossypii. J. Fungi 2020, 6, 157. [CrossRef]

2. Jun, S.C.; Kim, J.H.; Han, K.H. The Conserved MAP Kinase MpkB Regulates Development and Sporulation without Affecting Aflatoxin Biosynthesis in Aspergillus flavus. J. Fungi 2020, 6, 289. [CrossRef]

3. Wasserstrom, L.; Wendland, J. Role of RIM101 for Sporulation at Alkaline pH in Ashbya gossypii. J. Fungi 2021, 7, 527. [CrossRef]

4. Arai, K.; Sato, M.; Tanaka, K.; Yamamoto, M. Nuclear Compartmentalization is Abolished during Fission Yeast Meiosis. Curr. Biol. 2010, 20, 1913-1918. [CrossRef]

5. Yang, H.J.; Asakawa, H.; Ohtsuki, C.; Haraguchi, T.; Hiraoka, Y. Transient Breakage of the Nucleocytoplasmic Barrier Controls Spore Maturation via Mobilizing the Proteasome Subunit Rpn11 in the Fission Yeast Schizosaccharomyces pombe. J. Fungi 2020, 6, 242. [CrossRef] [PubMed]

6. Durant, M.; Roesner, J.M.; Mucelli, X.; Slubowski, C.J.; Klee, E.; Seitz, B.C.; Wallis, Z.; Huang, L.S. The Smk1 MAPK and Its Activator, Ssp2, Are Required for Late Prospore Membrane Development in Sporulating Saccharomyces cerevisiae. J. Fungi 2021, 7, 53. [CrossRef]

7. Coluccio, A.; Bogengruber, E.; Conrad, M.N.; Dresser, M.E.; Briza, P.; Neiman, A.M. Morphogenetic Pathway of Spore Wall Assembly in Saccharomyces cerevisiae. Eukaryot. Cell 2004, 3, 1464-1475. [CrossRef] [PubMed]

8. Zhang, B.; Teraguchi, E.; Imada, K.; Tahara, Y.O.; Nakamura, S.; Miyata, M.; Kagiwada, S.; Nakamura, T. The Fission Yeast RNA-Binding Protein Meu5 Is Involved in Outer Forespore Membrane Breakdown during Spore Formation. J. Fungi 2020,6 , 284. [CrossRef] [PubMed]

9. Tahara, Y.O.; Miyata, M.; Nakamura, T. Quick-Freeze, Deep-Etch Electron Microscopy Reveals the Characteristic Architecture of the Fission Yeast Spore. J. Fungi 2020, 7, 7. [CrossRef]

10. Basiony, M.; Yang, Y.; Liu, G.; Gao, X.D.; Nakanishi, H. Studies on the Properties of the Sporulation Specific Protein Dit1 and its Product Formyl Tyrosine. J. Fungi 2020, 6, 77. [CrossRef] [PubMed]

11. Lin, C.P.; Kim, C.; Smith, S.O.; Neiman, A.M. A Highly Redundant Gene Network Controls Assembly of the Outer Spore Wall in S. cerevisiae. PLoS Genet. 2013, 9, e1003700. [CrossRef]

12. Chrissian, C.; Lin, C.P.; Camacho, E.; Casadevall, A.; Neiman, A.M.; Stark, R.E. Unconventional Constituents and Shared Molecular Architecture of the Melanized Cell Wall of C. neoformans and Spore Wall of S. cerevisiae. J. Fungi 2020, 6, 329. [CrossRef]

13. Dijksterhuis, J.; Wyatt, T.; Hanssen, M.; Golovina, E.; Hoekstra, F.; Lugones, L. Abundant Small Protein ICARUS Inside the Cell Wall of Stress-Resistant Ascospores of Talaromyces macrosporus Suggests a Novel Mechanism of Constitutive Dormancy. J. Fungi 2021, 7, 216. [CrossRef] [PubMed] 